\title{
SEASONAL EARTHWORM DENSITIES ON ENDOPHYTE- INFECTED AND ENDOPHYTE-FREE PERENNIAL RYEGRASS
}

\author{
R.A. PRESTIDGE, S.L. MARSHALL and E.R. THOM ${ }^{1}$ \\ AgResearch, Ruakura Research Centre, Private Bag 3123, Hamilton \\ ${ }^{I}$ Dairying Research Corporation, Private Bag 3123, Hamilton
}

\begin{abstract}
Earthworms (Lumbricidae) are an important component in soils in many regions of New Zealand. Four 2.5 ha farmlets based on endophyteinfected and endophyte-free ryegrass were established in March 1993 with or without white clover (Trifolium repens). The abundance of two earthworm species, Aporrectodea caliginosa and Lumbricus rubellus, was monitored mid-season from July 1993 to July 1995 on a trial comparing the effects of ryegrass endophyte (Neotyphodium lolii) on cow health and milksolids production. Earthworms were sampled over two years by immersing soil divots in $4 \%$ formalin solution and counting emergence from the soil. A. caliginosa was about two times more abundant than L. rubellus. There were no consistent relationships between earthworm abundance and the presence of endophyte in ryegrass, or with the clover content of the pastures.

Keywords: Aporrectodea caliginosa, Lumbricus rubellus, Neotyphodium lolii, endophyte, earthworms
\end{abstract}

\section{INTRODUCTION}

Research in several countries (New Zealand, Ireland, The Netherlands, Australia) has shown that earthworms can have marked beneficial effects on soil structure and fertility, increase pasture and crop production and reduce soil degradation (Sharpleyet al. 1979; Stockdill 1982; Lee 1985; Temple-Smith 1991).

Although there are about 190 native New Zealand species of earthworm (Megascolecidae), most live in forest habitats and are not well adapted to the change in land use from forest to pasture. The earthworm fauna of known agricultural importance in New Zealand comprises 16 species of soil forming Lumbricidae, which have been introduced from Europe.

Several farm management practices are known to limit establishment and activity of Lumbricidae earthworms (Springett 1985). For example, earthworms are sensitive to drainage and irrigation, agricultural chemicals such as fungicides, pesticides and fertilisers, grazing management (intensity and frequency of defoliation) and cultivation. To gain maximum benefit from earthworms, farm management practices that adversely affect the ecology and functioning of earthworms should be avoided if possible.

The majority of pastures in New Zealand contain perennial ryegrass (Lolium perenne L.) and white clover (Trifolium repens L.). A large proportion of perennial ryegrasses are infected with an endophytic fungus, Neotyphodium lolii Glenn, Bacon and Hanlin, (formerly Acremonium lolii Latch, Christensen and Samuels). N. loliiinfected perennial ryegrass produces a number of chemical alkaloids which adversely affect the survival, development and reproduction of a range of insect species (eg. Prestidge and Ball 1996). The effects of these alkaloids on earthworms have not been reported. Some of these alkaloids also adversely affect grazing animals. New ryegrass/ endophyte associations are being developed which will alleviate adverse effects of endophyte on grazing animals. Prior to the widespread adoption and spread of new ryegrass/ $N$. lolii associations, information is urgently required on species abundance and diversity of beneficial organisms with existing "wild-type" strains of endophyte, so that the biological balance existing between pest and predator species is maintained. 
This paper reports on the abundance of two common introduced earthworm species in Waikato dairy pastures sown with $N$. lolii-infected and $N$. lolii-free perennial ryegrass, and with and without white clover.

\section{METHODS}

The trial was located at the Dairying Research Corporation, No. 5 Dairy, Hamilton, New Zealand. Soils were fertile silt loams, peaty silt loams and peaty clay loams. The annual rainfall for the site was $1178 \mathrm{~mm}$ and $1442 \mathrm{~mm}$ in 1994 and 1995, respectively. Full details of methodology are provided in Thomet al. (1994). Treatments were established in March 1993 as four 2.5 ha farmlets. Resident pasture was killed with glyphosate herbicide $(0.72$ $\mathrm{kg} / \mathrm{ha}$ ), the pasture was grazed after 5 days, and perennial ryegrass cv. Yatsyn 1 was crossdrilled ( $7 \mathrm{~kg} / \mathrm{ha}$ each pass) to establish a new sward. Half the trial area (20 paddocks each 0.25 ha) was drilled with ryegrass seed with $85 \%$ infection level of $N$. lolii and the remainder with seed free of endophyte. Half the paddocks sown in ryegrass were also sown with $3 \mathrm{~kg} /$ ha white clover $\mathrm{cv}$. Grasslands Kopu, while the remaining paddocks were treated with dicamba $(0.40 \mathrm{~kg} / \mathrm{ha})$ and MCPA $(0.75 \mathrm{~kg} / \mathrm{ha})$ to remove resident clovers and flatweeds. Nitrogen fertiliser was added to the clover-free plots after each grazing at a rate equivalent to that removed by animals. The four treatments were randomly arranged within five blocks in a $2 \times 2$ factorial design.

The paddocks sown with endophyte-free ryegrass seed were undersown using the original seedline in May 1994 in an attempt to reduce the percentage contamination of volunteer ryegrass plants infected with $N$. lolii.

The trial was rotationally grazed by dairy cows as part of the normal farm practice. The first grazing occurred in mid-May 1993 about 8 weeks after drilling.

The percentage of ryegrass plants infected with $N$. lolii was assessed by removing one tiller from 20 randomly selected ryegrass plants per endophyte-free sown paddock and 10 ryegrass plants from endophyte-infected sown paddocks. The outermost sheath associated with a green leaf was stained with lactophenol - aniline blue and examined for $N$. lolii endophyte under a light microscope at 200x magnification.

Earthworm populations were sampled in winter (July), spring (October), summer (January) and autumn (April) by taking a soil divot $(15 \times 15 \mathrm{~cm})$ to $15 \mathrm{~cm}$ depth from 10 randomly selected positions, $10 \mathrm{~m}$ apart along a diagonal transect within each paddock. Soil divots were inverted for 10 minutes in buckets containing $4 \%$ formalin solution and the number of earthworms that emerged were identified and counted.

Data were statistically analysed by ANOVA.

\section{RESULTS}

The percentage of $N$. lolii-infected ryegrass plants in the paddocks sown with endophyte-free seed continued to increase for the duration of the trial (Fig. 1). Undersowing endophyte-free ryegrass seed in May 1994 was only temporally successful with an initial decrease in endophyte-infected ryegrasses recorded in August 1994. However, it appears that this effect was rapidly lost as the percentage of $N$. lolii-infected ryegrasses increased on average from $15 \%$ to $42 \%$ by February 1995 . In contrast, the percentage of $N$. loliiinfected ryegrasses in the areas sown with $N$. lolii-infected seed was on average never less than $83 \%$.

The percentage of $N$. lolii-infected ryegrass plants on paddocks containing white clover was significantly less than $(\mathrm{P}<0.01)$ plots without white clover (Fig. 1).

Four earthworm species were recorded, but numbers of Lumbricus terrestris and Octolasion cyaneum were too low for statistical analyses to be conducted. Densities of adult and juvenileAporrectodea caliginosa were approximately twice that of Lumbricus rubellus (Fig. 2). Seasonal patterns of abundance were evident in both species and densities were lowest in summer.

Earthworm densities (adults, juveniles, and adults + juveniles) were only occasionally significantly different $(\mathrm{P}<0.05)$ in areas supporting $N$. lolii-infected and $N$. lolii-free perennial ryegrass. However there was no consistent trend of earthworm densities with presence or absence of endophyte throughout the duration of the trial. The presence or absence of white clover also had no effect on earthworm densities. 


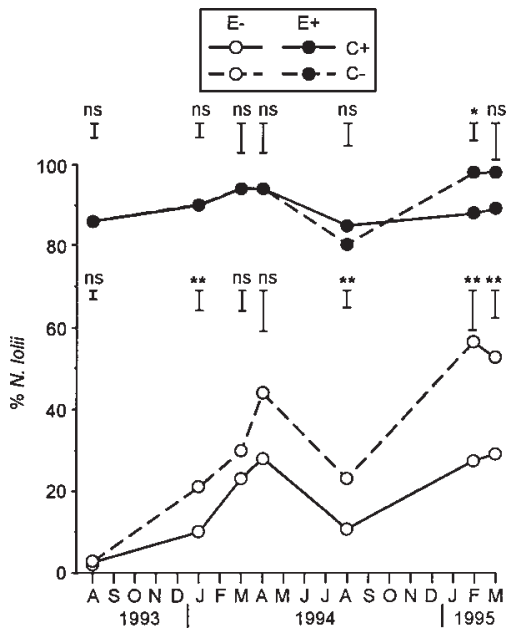

FIGURE 1: The percentage of perennial ryegrass plants infected with $N$. lolii in paddocks sown with $N$. lolii-infected $\left(\mathrm{E}^{+}\right)$and $N$. lolii-free $\left(\mathrm{E}^{-}\right)$seed and with $\left(\mathrm{C}^{+}\right)$and without $\left(\mathrm{C}^{-}\right)$white clover. Vertical bars are SED.

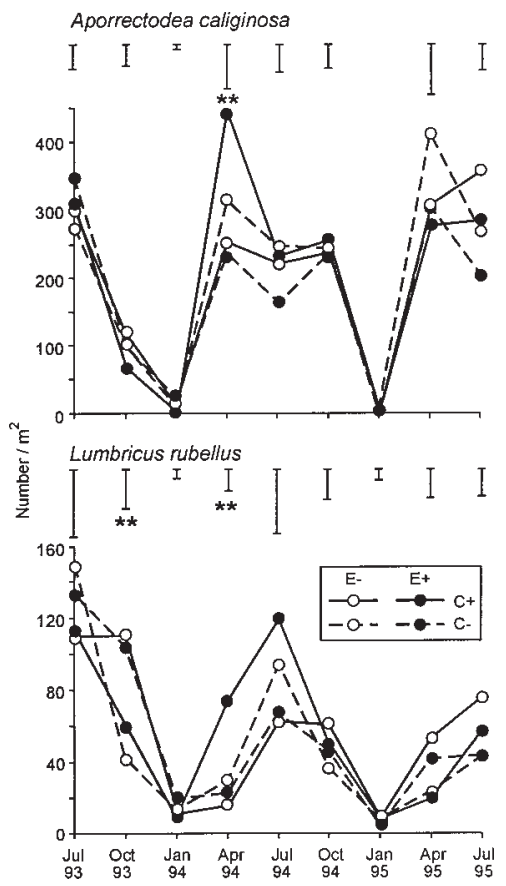

FIGURE 2: The number of earthworms $/ \mathrm{m}^{2}$ (Lumbricidae) in paddocks sown with $N$. lolii-infected $\left(\mathrm{E}^{+}\right)$and $N$. lolii -free $\left(\mathrm{E}^{-}\right)$perennial ryegrass and with $\left(\mathrm{C}^{+}\right)$and without $\left(\mathrm{C}^{-}\right)$white clover. Vertical bars are SED. 


\section{DISCUSSION}

The increase in the percentage of $N$. lolii-infected plants in pastures sown with $N$. lolii-free ryegrass seed was a cause for concern and experiments are currently underway to determine the reasons for this. In previous studies where contamination of endophyte-free areas has occurred (eg. Prestidge and Ball 1996), predation by Argentine stem weevil (Listronotus bonariensis (Kuschel)) on $N$. lolii-free ryegrass caused an increase in the percentage of $N$. lolii-infected plants, but a decrease in overall tiller and plant density. In the current study, Argentine stem weevil adult populations were low and were unlikely to have been responsible for the increase (Prestidge and Thom, Unpublished). It appears likely that another source of $N$. lolii-infected ryegrass seed from outside the trial paddocks was responsible for the increase in the percentage of endophyte-infected ryegrass in the endophyte-free areas. Other sources may also have contributed to the increase in endophyte infection such as seed in the seedbank at sowing and a lower than desirable kill of resident ryegrasses with glyphosate. Contamination via hay was not possible as hay was not fed on the trial area for the duration of the study.

The percentage of $N$. lolii-infected plants was less in paddocks containing white clover than in clover-free paddocks. A plausible explanation could be that white clover occupied spaces between the ryegrass drill rows reducing colonisation by $N$. loliiinfected volunteer ryegrass seedlings. Other explanations are possible, such as animals selectively grazing the areas occupied by white clover and thereby consuming ryegrass seedlings also growing in these areas, and chemical interactions between white clover and ryegrass seedlings.

Both $A$. caliginosa and $L$. rubellus are common in soils in the Waikato at densities similar to those recorded on this trial (Rohitha et al. 1985). L. rubellus is considered a shallow burying species which feeds mainly on dung. A. caliginosa feeds on dead plant material and is considered a topsoil mixing earthworm. Both species often occur together in most soil types. There was no evidence from the current study that A. caliginosa or $L$. rubellus were affected by $N$. lolii-infected ryegrass. A number of alkaloids produced by the association of $N$. lolii and ryegrass influence herbivorous insects (Prestidge and Ball 1996), invertebrate predators (Prestidge and Marshall 1997) and grazing animals (Prestidge 1993). Some alkaloids persist in chemically killed ryegrasses for at least 28 days (Prestidge and Sprosen 1995). It has been shown that some dung feeding insects are adversely affected by feeding on dung from cattle grazing $N$. coenophialum-infected tall fescue (Festuca arundinacae), a close relative of perennial ryegrass (Dougherty and Knapp 1994). Hence, it is likely that earthworms regularly come in contact with alkaloids produced by $N$. lolii-infected ryegrass, either by feeding on dung (L. rubellus) or ingesting dead and decaying plant tissues (A. caliginosa).

It was surprising that the densities of earthworms were not affected by the contrasting clover treatments. The quality and amount of food available influences the size of earthworm populations, the diversity of species present and their rate of growth and fecundity (Edwards and Lofty 1975). Earthworms grew faster and had higher fecundity when feeding on nitrogen-rich diets such as litter from ryegrass and white clover (Edwards and Lofty 1975). It is possible that the short-term nature of this trial contributed to the lack of any effect on earthworm populations. Controlled feeding studies may be necessary to ascertain the long term effects on earthworm populations in the absence of white clover.

\section{ACKNOWLEDGEMENTS}

We thank Catherine Cameron for biometrical help and advice, and Liz Wilson and Hugh Oliver for help with earthworm sampling and extraction.

\section{REFERENCES}

Dougherty, C.I. and Knapp, F.W., 1994. Oviposition and development of face flies in dung from cattle on herbage and supplemented herbage diets. Vet. Parasit. 55: 1-2. Edwards, C.A. and Lofty, J.R., 1975. Biology of Earthworms. Chapman and Hall Ltd, 
London.

Lee, K.E., 1985. Earthworms : their Ecology and Relationships with Soil and Land Use. Academic Press, Sydney.

Prestidge, R.A., 1993. Causes and control of perennial ryegrass staggers in New Zealand. Agri. Eco. and Envir. 44: 283-300.

Prestidge, R.A. and Sprosen, J.M., 1995. The effect of glyphosate, paraquat and paclobutrazol on lolitrem B levels in endophyte-infected perennial ryegrass. N.Z. Vet. J. 1995: 138-140.

Prestidge, R.A. and Ball, O.J-P., 1996. A catch 22 : The utilization of endophytic fungi for pest management. Pp 171-192In: Multitrophic Interaction in Terrestrial Systems. A.C. Gange and V.K. Brown (Eds). Blackwell Science Ltd, Oxford.

Prestidge, R.A. and Marshall, S.L., 1997. The effects of Neotyphodium-infected perennial ryegrass on the abundance of invertebrate predators.Proc. 3rd Int. Symp. Acremonium/Grass Interactions: (in press).

Rohitha, B.H., Pottinger, R.P., Oliver, E.H. and Firth, A.C., 1985. Preliminary sampling studies on earthworms in three soil types in the Waikato. Proc. 4th Aust. Conf. Grassl. Invert. Ecol. : 52-57.

Sharpley, A.N., Syers, J.K. and Springett, J.A., 1979. Effect of surface-casting earthworms on the transport of phosphorus and nitrogen in surface runoff from pasture. Soil Biol. Biochem. 11: 459-462.

Springett, J.A., 1985. National assessment of soil-forming Lumbricidae in New Zealand. Proc. 4th Aust. Conf. Grassl. Invert. Ecol. : 46-51.

Stockdill, S.M.J., 1982. Effects of introduced earthworms on the productivity of New Zealand pastures. Pedobiologia 24: 29-35.

Temple-Smith, M.G., 1991. Earthworm populations and their effects on pasture production. Australian Inst. of Agri. Sc. Occ. Pub. No 62: 11-15.

Thom, E.R., Clark, D.A., Prestidge, R.A., Clarkson, F.H. and Waugh, C.D., 1994. Ryegrass endophyte, cow health and milksolids production for the 1993/94 season. Proc. N.Z. Grassl. Ass. 56: 259-264. 